\title{
Effect of Intra-mammary infusion of Moringa oleifera on somatic Cell Count [SCC] and Total Bacterial Count [TBC] in cows with Staphylococcus aureus clinical mastitis
}

\author{
Swati Sahay*, Mitali Das, Arun Prasad ${ }^{1}$, Madhurendu Kumar Gupta ${ }^{2}$, Ansar Ahmad and Arvind Sharma ${ }^{3}$ \\ Department of Veterinary Medicine, Ranchi Veterinary College, Birsa Agricultural University, Kanke, Ranchi \\ (Jharkhand) India (Email: sahayswati20@gmail.com)
}

\begin{abstract}
Therapeutic efficacy of hydro-methanolic extract of M. oleifera was evaluated in lactating cows with Staphylococcusaureus clinicalmastitis.Mastiticcows,screened and selected on the basis of CMT,SCC and cultural examination, were divided in two groups of five animals each.Intra-mammary infusion of Hydro-methanolic extract of M.oleifera@1 g/10 ml of PBS intramammary once daily for 7 days resulted in reduction of $90.9 \%, 93.04 \%$ and $83.98 \%$ inCMT, SCC and TBC on day 14 of treatment which was comparable with that of group I with ceftriaxone.
\end{abstract}

Key Words : M.oleifera, Staphylococcus aureus, clinical mastitis, CMT, SCC,TBC

View Point Article : Sahay, Swati, Das, Mitali, Prasad, Arun, Gupta, Madhurendu Kumar, Ahmad, Ansar and Sharma, Arvind (2021). Effect of Intra-mammary infusion of Moringa oleifera on somatic Cell Count [SCC] and Total Bacterial Count [TBC] in cows with Staphylococcus aureus clinical mastitis.Internat. J. agric. Sci., 17 (AAEBSSD) : 222-228, DOI:10.15740/HAS/IJAS/17-AAEBSSD/222-228. Copyright@2021: Hind Agri-Horticultural Society.

Article History : Received : 27.07.2021; Revised : 30.07.2021; Accepted : 01.08.2021

\section{INTRODUCTION}

Mastitis is one of the major problems of dairy industry causing huge economic losses. The losses are mostly quantitative in the form of reduced milk production along with deterioration in physical, chemical and bacteriological quality of milk (Raza et al., 2013). It has been documented those losses due to mastitis has increased 114-fold in about four decades from 529 million/ annum to 60532 million annum up to 2001 (Dua,2001). Nonetheless, Staphylococcus aureus is number one mastitis causing pathogen in India (Athar, 2007, Sharma et al., 2007, Sumathi et al.,2008, Padhy et al.,2014).

Mastitis is caused by a whole consortium of more than 137 pathogenic micro-organisms. Staph. aureus forms micro-abscesses or granulomas in the mammary gland tissues and there is usually low response to orthodox antibiotic therapy due to intracellular localization of organism in the mammary gland epithelial cells.

Indiscriminate use of commonly used antibiotics such as Penicillin, Ampicillin, Streptomycin, Tetracycline and Oxytetracycline has led to development of drug

\footnotetext{
*Author for correspondence:

${ }^{1}$ Department of Veterinary Microbiology, Ranchi Veterinary College, Birsa Agricultural University, Kanke, Ranchi (Jharkhand) India

${ }^{2}$ Department of Veterinary Pathology, Ranchi Veterinary College, Birsa Agricultural University, Kanke, Ranchi (Jharkhand) India

${ }^{3}$ Department of Veterinary Surgery, Ranchi Veterinary College, Birsa Agricultural University, Kanke, Ranchi (Jharkhand) India
} 
resistance leading to treatment failure in mastitis (Owens et al.,1997, Tung, 2004). Methicillin resistant S.aureus has become a treatment challenge for veterinarians and has created additional public health concern due to its recent emergence as community acquired pathogen (Sato et al.,2017). With the increasing problems of drug resistance and other adverse effects, herbal plants are reviewed for their potential use as complementary and Alternative Medicine (Cowan,1999), Traditional healing system around the world that utilized herbal remedies were an important source for discovery of new antibiotics (Samy and Gopalkrishnakone, 2008).

Moringa oleifera commonly known as "Drumstick or Horse radish tree" is a member of the moringaceae family (Olson,2002) and a native of sub-Himalayan northern parts of India. A wide variety of nutritional and medicinal virtues have beenattributed to its roots, bark, leaves, flowers fruits and seeds (Ramchandran et al.,1980). The plant is rich in a unique group of compounds called glucosinolates and isothiocyanates reported to have potent hypotensive, anti-cancer,antioxidant and anti-bacterial properties against a variety of pathogens including Staph. aureus, Staph . epidermidis, S.pyogenes, E.coli etc. (Renitta et al., 2009, Dewangan et al., 2010). The hydro-ethanolic extract of M.oleifera is stated to possess high amount of flavonoids, polyphenols and tocoferol showing significant anti-oxidant potential (Siddiq et al., 2005, Sreelatha and Padma, 2009, Das and Kanodia, 2012 and Oybrinugafor et al., 2012).

Inline with the anti-bacterial, anti-inflammatory and anti-oxidant properties of M.oleifera, the objectives of this research were to assess its therapeutic potential as an alternative / complementary therapy in clinical bovine mastitis.

\section{Material AND Methods}

\section{Collection of plant materials:}

M. oleifera leaves were collected locally from the campus of Ranchi Veterinary College, Kanke, Ranchi, Jharkhand. The collected leaves were identified and authenticated by Professor, Department of Botany, Ranchi University, Jharkhand, India.

\section{Preparation of extract:}

The leaves of M.oleifera were shade dried and ground to powder. Hydro-ethanolic extract was prepared by dissolving $500 \mathrm{~g}$ of ground leaves in 2.0 litres of $80 \%$ methanol kept at room temperature with occasional shaking. After three days, extract was filtered off by using sterile whatmann filter paper no 1 . The resultant methanolic extract was concentrated and evaporated to drynessbelow $40^{\circ} \mathrm{C}$ to yield a semisolid mass. The standard extract was reconstituted in sterile phosphate buffer saline (PBS, pH-7.4) $1 \mathrm{~g}$ extract/10ml of PBS. The reconstituted extract was filtered through a membrane filter ( $0.22 \mathrm{um}$ pore size, Millipore, Bangalore Pvt. Ltd.,India) and refrigerated in a sterile vial for intramammary infusion. The dose was selected on the basis of previous research.

\section{Standard antibiotic:}

Ceftriaxone was selected for the present study on the basis of in vitro sensitivity test by standard disc diffusion method.

\section{Experimental design:}

Animals :

The study was carried in a Military Dairy Farm, Namkum,Ranchi,Jharkhand in cross bred dairy cows maintained under identical feedingand management practices. Ten (10) cows, out of a total 95, selected on the basis of physical examination, CMT, SCC and cultural examination were divided into two groups of five animals each. The cows were subjected to the treatment schedule for seven days (Table A). The study was approved by International Animal Ethics committee as per CPCSEA guidelines.

\begin{tabular}{|lll|}
\hline Gr. & Treatment Schedule & Dose, Route and Duration \\
\hline I & Hydro-methanolic & $1 \mathrm{~g} / 10 \mathrm{ml}$ of PBS intramammary \\
& extract of M.oleifera & once daily for 7 days. \\
II & Ceftriaxone & $500 \mathrm{mg}$ Intramammary once daily \\
& & for7 days. \\
\hline
\end{tabular}

\section{Milk sampling:}

$50 \mathrm{ml}$ of milk sample was collected from each cow in sterile vial after cleaning the teat with $70 \%$ of ethanol and discarding a few streams of milk. Samples were collected on day 0 and thereafter on day 3,7 and 14 . Somatic cell count was performed as per Schalm et al., 1971. California mastitis test was using CMT commercial reagent (Delavel) as per Schalm and Noorlander,1957. Total bacterial count (TBC) was performed per standard method described by Griffin et al., 1977. For bacteriological examination of milk samples 
and the analysis of bacterial growth, milk samples were inoculated on blood agar plates incubated for 24 and 48 hours at $37^{\circ} \mathrm{C}$. The organisms were identified on the basis of cultural and biochemical characteristics, grams staining and growth on selective media.

\section{Statistical methods:}

Statistical analysis of data was done as per the method suggested by Snedecor and Cochran (2004).

\section{RESUlts AND Discussion}

M. oleifera hydro-methanolic extract showed good in-vitro anti-microbial activity against a number of microorganisms including coagulase +veStaph.aureus, coagulase-ve Staph.Sp., Streptococcus sp. and E.coli, commonly associated with mastitis in cows.In the present study, S. aureus was isolated as the major mastitis causing organism followed by Streptococcus sp. and E. coli etc. Staph. aureus is reported as one of most representative pathogenic bacteria causing bovine mastitis and is widely distributed in dairy cattle herds in several countries (Schmidt et al., 2017). Staph sp. was enumerated as the major causative agent of clinical mastitis in bovines of Jammu region (Bhatet al., 2017). Many studies from Asian countries have also reported that Staph. aureus is the chief etiological agent of mastitis in cattle and buffaloes (Kang -Hee et al., 2001, Sharma et al., 2007, Abdul-Rady and Sayed, 2009; Rahman et al., 2010, Sharma and Maiti, 2010).

Use of anti-biotics is a major drawback in the treatment of Staph aureus mastitis because of high resistance, poor response and chronic nature of infection. Also, there is limitation in antibiotic usagedue torise of antibiotic residues in milk. Furthermore, anti-biotic therapy can impede the normal defense mechanism of the udder by decreasing phagocytic function exacerbating inefficiency of phagocytes and subsequent relapse of function (Aboul-Ela., 2002). The obstacles in the control of $S$. aureus mastitis have paved the way for alternative approaches in its therapy and management.Antibiotic screening of natural products obtained from $M$. oleifera used in thecomplementary and alternative medicine (CAM) is amajor thrust area of research and development.

\section{CMT score, SCC and total bacterial count:}

The therapeutic efficacy of hydro-methanolic extract of M.oleifera was evaluated in terms of CMT,SCC and TBC intwo experimental groups I and II, respectively. The initial mean CMT point score was $2.2 \pm 0.20$ and $2.4 \pm 0.24$ on day 0 in group I and II, respectively (Table 1 and 2). The initial mean SCC was recorded as $43.12 \pm 5.76 \times 10^{5} \mathrm{cells} / \mathrm{ml}$ and $44.50 \pm 3.47 \mathrm{X}$ $105 \mathrm{cells} / \mathrm{ml}$ for group I and II, respectively. Group I cow treated with M.oleifera extract showed reduction of $90.9 \%$ in CMT score and $93.04 \%$ in SCC onday 14 of treatment which was comparable with respective score in antibiotic treated group $(91.67 \%$ and $92.18 \%$ reduction in CMT and SCC). Complementary results were observed with TBC as bacterial count was reduced to $4.19 \pm 6.08 \times 10^{3} / \mathrm{ml}$ with $83.98 \%$ inhibition in group I while a lower inhibition (69.24\%) was observed in group II.

Numerous studies have identified compounds within herbal plants that are effective as antibacterial agents (Parekh and Chanda, 2007). The hydro-methanolic extract of $M$. oleifera showedgood in -vitro antimicrobial activity against a number of micro-organisms including Staph.aureus. Accordingly, in vivo efficacy of the extract was evaluated by monitoring CMT score and SCC indices of treated cows. The amount of gel formation in CMT test corresponds to increase in number of leucocytes present during inflammation of mammary gland which is characteristic of mastitis.Also, high CMT score indicates high SCC value.

In the present study, the anti-inflammatory activity of the extract was not independently tested but the reduction in mastitis score (CMT and SCC) suggests an anti-inflammatory activity along with anti-microbial

\begin{tabular}{|c|c|c|c|c|}
\hline Parameters & & & & \\
\hline$(n=5)$ & 0 & 3 & 7 & 14 \\
\hline CMT & $2.20 \pm 0.20^{\mathrm{C}}$ & $2.00 \pm 0.00^{\mathrm{C}}$ & $1.40 \pm 0.24^{\mathrm{B}}$ & $0.2 \pm 0.20^{\mathrm{A}}$ \\
\hline SCC & $43.12 \pm 5.76^{\mathrm{C}}$ & $24.10 \pm 4.18^{\mathrm{B}}$ & $13.90 \pm 0.91^{\mathrm{B}}$ & $3.0 \pm 0.79^{\mathrm{A}}$ \\
\hline TBC & $26.08 \pm 1.54^{\mathrm{D}}$ & $18.04 \pm 1.61^{\mathrm{C}}$ & $8.46 \pm 133.43^{\mathrm{B}}$ & $4.2 \pm 6.08^{\mathrm{A}}$ \\
\hline
\end{tabular}

**Values with different superscript in rows differs significantly $(\mathrm{p} \leq 0.05)$ 
Swati Sahay, Mitali Das, Arun Prasad, Madhurendu Kumar Gupta, Ansar Ahmad and Arvind Sharma

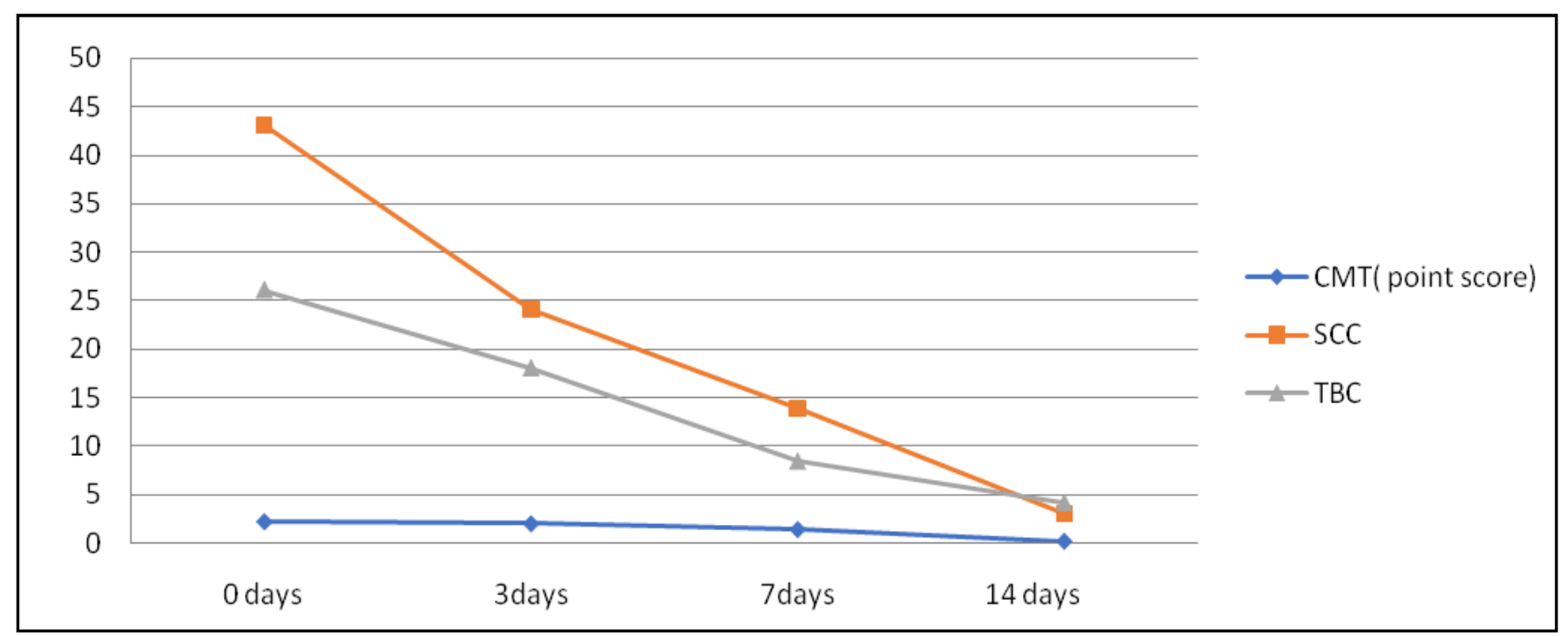

Fig. 1: Graph showing therapeutic effect of $M$. oleifera extract on the basis of average CMT point score, SCC and TBC

\begin{tabular}{|c|c|c|c|c|}
\hline \multirow{2}{*}{$\begin{array}{l}\text { Parameters } \\
(\mathrm{n}=5)\end{array}$} & \multicolumn{4}{|c|}{ Days post treatment } \\
\hline & 0 & 3 & 7 & 14 \\
\hline CMT & $2.40 \pm 0.24^{\mathrm{C}}$ & $2.00 \pm 0.00^{\mathrm{C}}$ & $1.00 \pm 0.00^{\mathrm{B}}$ & $0.20 \pm 0.20^{\mathrm{A}}$ \\
\hline $\mathrm{SCC}$ & $43.50 \pm 5.27^{\mathrm{C}}$ & $18.60 \pm 1.70^{\mathrm{B}}$ & $13.60 \pm 0.89^{\mathrm{B}}$ & $3.40 \pm 0.66^{\mathrm{A}}$ \\
\hline TBC & $20.94 \pm 2.60^{\mathrm{B}}$ & $16.60 \pm 2.52^{\mathrm{B}}$ & $10.66 \pm 41.55^{\mathrm{A}}$ & $6.44 \pm 7.99^{\mathrm{A}}$ \\
\hline
\end{tabular}

**Values with different superscript in rows differs significantly (p? 0.05 )

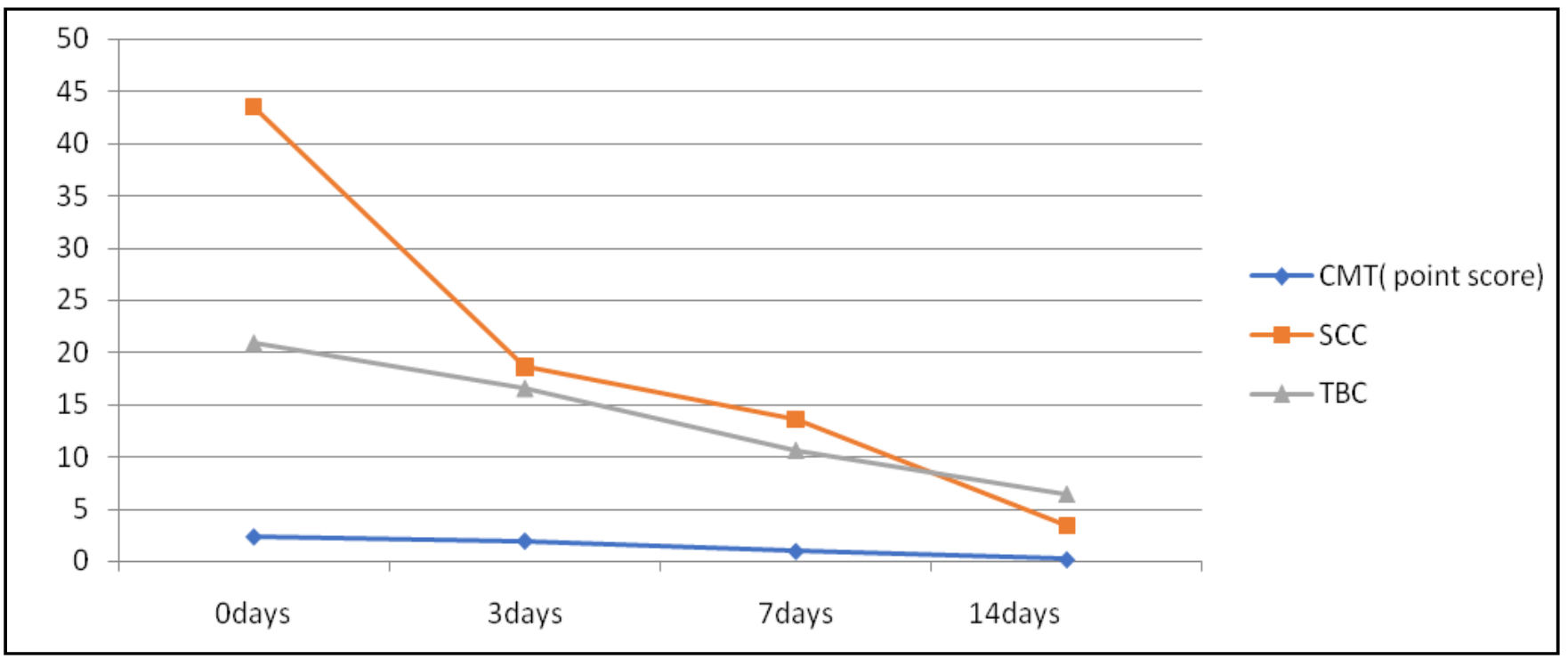

Fig. 2: Graph showing therapeutic effect of ceftriaxone on the basis of CMT point score, SCC and TBC

effect of the extract. The observation could be corelated by the known anti-inflammatory activity of M.oleifera against carrageenan induced paw edema in mice (Medhi et al.,2003), carrageenan induced paw edema and cotton pellet granuloma formation in rats (Kumbhare and Thangaveel, 2011, Bhattarcharya et al.,1982).

Rajnarayana et al., 2001 reported flavonoids potently inhibit biosynthesis of prostaglandins which are 
mediators of inflammation through cyclooxygenase and lipoxygenase pathways. Manthey et al., 2001 suggested that flavonoids inhibit inflammatory processes through inhibition of regulatory enzymesprotein kinases that mediate adhesion of circulating leukocytes to sites of injury. Analgesic, and anti-inflammatory effect of M.oleifera might be due to flavonoids, steroids and tannins as reported by Bhujbal et al., 2008.

Total bacterial count of milk sample is an index of the quality of milk, herd health, efficacy of farm sanitation, milk handling and storage/transportation temperature. Gunawardana et al., 2011 stated thatcows with mastitis contribute to high TBC with shedding of $1,000,000$ bacteria/ $\mathrm{ml}$. According to Gianina et al. 2003, the antibacterial activity of $M$. oleifera might be attributed to the presence of alkaloids such asmoringine, moringinine and spirachin, as well as pterygospermin.Bukar et al., 2010 argued that the presence of a short polypeptide named 4-(alpha-L-rhamnosyloxy) benzyl-isothiocyanate in M.oleifera extract might exert its anti-microbial action through growth inhibition by disrupting cell membrane synthesis, a mechanism of action similar to the $\beta$-Lactam and cephalosporin antibiotics.Flavonoids exhibit their antibacterial activity against a large number of microorganisms by inhibition of the membrane-bound enzymes (Pretorious, 2003). Tannins are polyphenols with pronounced ability to suppress bacterial cell proliferation by blocking essential enzymes of microbial metabolism such as the proteolytic macerating enzymes (Kamba and Hassan, 2010). Saponins exert some antibacterial activity by combining with cell membranes to elicit changes in cell morphology leading to cell lysis (Moyo et al., 2012).Terpenoids and steroids were detected in M. oleifera which were reported to be active against Staphylococcus aureus (Cowan, 1999). A number of authors has observed good antibacterial effect of aqueous and ethanolic leaf extracts of Moringa oleifera on the growth of gram-positive and negative bacteria (Dewagan et al., 2010, Devendra et al., 2011, Peixoto et al., 2011). The phytochemical analysis of $M$. oleifera leaf extract is reported to contain an array of bio-active compounds such as alkaloids, glycerides, flavonoids, steroids, terpenoids, saponins, tannins and anthraquinone. (Faizi et al.,1994 and 1995; Bennett et al., 2003; Price, 2007; Singh et al., 2009; Sreelatha et al., 2011). The major flavonoids found in M.oleifera are myrecetin, quercetin and kaempferol (Coppin et al., 2013). The significant inhibition of M. oleifera in the present study might be due to plethora of phytoconstituents present in the leaf fraction of the plant.

\section{Conclusion:}

Intramammary administration of hydro-methanolic extract of $M$. oleifera reduced bacterial count in milk, CMT score and SCC exhibiting both anti-bacterial and anti-inflammatory activity. Therefore, it may be concluded that the hydro-methanolic extract of $M$. oleifera possesses good therapeutic potential against bovine mastitis and can be used as suitable alternative therapy.

\section{Acknowledgement:}

The authors would like to acknowledge Birsa Agricultural university for providing financial support for the research work.

\section{REFERENCES}

Abdel-Rady, A. and Sayed, M. (21009). Epidemiological Studies on Subclinical Mastitis in Dairy cows in Assiut Governorate. Veterinary world, $2: 2009$.

Aboul-Ela, E. I. (2002). Cytogenetic studies on Nigella sativa seeds extract and thymoquinone on mouse cells infected with schistosomiasis using karyotyping. Mutation Res. /Genetic Toxicol. Environ. Mutage., 516 : 11-17.

Athar, M. (2007). Preparation and evaluation of inactivated polyvalent vaccines for control of mastitis in dairy buffaloes, Ph.D. Thesis, Deptt. of Clinical Medicine and Surgery, University of Agriculture Faisalabad, Pakistan.

Azadi, H.G. and Farzaneh, N. (2010). Comparison of two regimens of Nigella sativa extract for treatment of subclinical mastitis caused by Staphylococcus aureus. Am. J. Applied Sci., 7: 1210-1214.

Bennett, R. N., Mellon, F.A., Foidl, N., Pratt, J. H., Dupont, M. S., Perkins, L. and Kroon, P.A.(2003). Profiling glucosinolates and phenolics in vegetative and reproductive tissues of the multipurpose trees Moringa oleifera L. (Horseradish tree) and Moringa stenopetala L, Journal of Agriculture and Food Chemistry, 51 (12) : 3546-3553.

Bhat, A. M., Soodan, J. S. and Singh, R. (2017). Incidence of bovine clinical mastitis in Jammu region and antibiogram of isolated pathogens, Veterinary world, 10 : 984.

Bhattacharya, S.B., Das, A.K. and Banerji, N. (1982). Chemical investigations on the gum exudates from Sonja (Moringa oleifera). Carbohydr. Res., 102 : 253-262.

Bhujbal, S.S., Chitlange, S.S., Suralkar, A.A., Shinde, D.B. and Patil, M.J. (2008). Anti- inflammatory activity of an 
Swati Sahay, Mitali Das, Arun Prasad, Madhurendu Kumar Gupta, Ansar Ahmad and Arvind Sharma

isolated flavonoids fraction from Celosia argentea Linn. $J$. Med. Plants Res., 2 : 52-54.

Bukar, A., Uba, A. and Oyeyi, T. I. (2010). Antimicrobal profile of Moringa oleifera Lam. Extracts against some food borne microorganisms. Bayero Journal of Pure and Applied Sciences, 3(1): 43-48.

Cowan, M.M. (1999). Plant products as antimicrobial agents. Clinical Microbio. Reviews, 12 : 564-58.

Das, M. ( 2014 ). Therapeutic efficacy of M.oleifera in Bovine Mastitis, M.V. Sc. Thesis Birsa Agricutural University, Ranchi (Jharkhand) India.

Das, S. and Kanodia, L. (2012). Effect of ethanolic extract leaves of Moringa olifera Lam. on acetic acid induced colitis in albino ratsAsian Journal of Pharmaceutical and Clinical Research, 5 (3): 110-114.

Dewagan, G., Koley, K.M., Vadlamudi, V.P., Mishra, A., Poddar, A. and Hirpurkar, S.D. (2010). Antibacterial activity of Moringa oleifera (drumstick) root bark. J. Chem. Res., 2 (6): 424-428.

Dua, K. (2001). Incidence, etiology and estimated economic losses due to mastitis in Punjab and inIndia- an Update. Indian Dairyman, 53 : 41-48.

Faizi, S., Siddiqui, B.S., Saleem, R., Siddiqui, S., Aftab, K. and Gilani, A.H.(1994). Isolation and structure elucidation of new nitrile and mustard oil glycosides from Moringa oleifera and their effect on blood pressure. J. Nat. Prod., 57: 12561261.

Faizi, S., Siddiqui, B.S., Saleem, R., Siddiqui, S., Aftab, K. and Gilani, A.H. (1995). Fully acetylated carbamate and hypotensive thiocarbamate glycosides from Moringa oleifera. Phytochemistry, 38 (4) : 957-963.

Gianina, Martha A., Anit, Panaligan, Lauren Joyce R., Mendez and Verna Liz, S. (2003). The antimicrobial effects of malunggay root extract on E. coli, S. aureus and Candida albicans, Molecules, 117-129

Griffin, T. K., Dodd, F. H., Neave, F. K., Westgarth, G. R., Kindwill, R. G. and Wilson, C. D. (1977). A method of diagnosing intramammary infections in dairy cows for large experiments. J. Dairy Res., 44: 25-45.

Gunawardana, W.S.N., Abeynayake, P., Thilakarathne, D.S., Stephen, C. and Abeygunawardena, I.S. (2011). Establishing the Baseline Total Bacterial Count for Cows' Milk in Sri Lanka and its Application in Determining Bulk Milk Contamination. Proceedings of the Peradeniya University Research Sessions, Sri Lanka, 16, 24th November, 2011.

Kamba, A. S. and Hassan, L. G. (2010). Phytochemical screening and antimicrobial activities of Euphorbia balasamifera leaves, stem and root against some pathogenic microorganisms. African Journal of Pharmaceutical Sciences and Pharmacy., 1: 57-64.

Kang-Hee, J., H. Kim-Jin, G. Son-Won, S. and Lee-Du, H.J. (2001). Identification and antimicrobial susceptibility of microorganisms. Korean J. Vet. Res., 41: 511-521.

Kumbhare, M. and Thangavel, S. (2011). Anti-Inflammatory and analgesic activity of stem bark of Moringa oleifera. Pharmacologyonline, 3 : 641-650.

Medhi,B., Khanikor, H. N., Lahon, L. C., Mohan, P. and Barua, C. (2003). Analgesic, anti-inflammatory and local anaesthetic activity of moringa in laboratory animals. Pharmaceutical biology, 41: 248-252.

Moyo, B., Masika, P., Hugo, A. and Muchenje, V. (2012). Nutritional characterization of Moringa (Moringa oleifera Lam.) leaves, African Journal of Biotechnology, 12: 34-42.

Ogbunugafor, H., Igwo-Ezikpe, M., Igwilo, I., Ozumba, N., Adenekan, S., Ugochukwu, C., Onyekwelu, O. and Ekechi, A. (2012). In vitro and In vivo evaluation of antioxidant properties of Moringa oleifera ethanolic Leaves extract and effect on serum Lipid indices in Rat. Maced. J. Med. Sci.,1857-5773.

Olson, M.E. (2002). Combining data from DNA sequences and morphology for a phylogeny of moringaceae (Brassicales), 27(1) : 55-73.

Owens, W.E., Ray, C.H., Watts, J.L. and Yancey, R.J. (1997). Comparison of success of antibiotic therapy during lactation and results of antimicrobial susceptibility tests for bovine mastitis. J. Dairy Sci., 80 (2) : 313-317.

Padhy, A., Dalai, N., Shekhar, S., Sahu, A.R., Sahoo, S. and Kashyap, D.K. (2014). A microbial, antibiogramand hematological study of mastitis cows, Journal of Cell and Tissue Research, 14(3) : 4681-4684.

Parekh, J. and Chanda, S. (2007). In vitro screening of antibacterial activity of aqueous and alcoholic extracts of various Indian plant speciesagainst selected pathogens from Enterobacteriaceae African Journal of Microbiology Research, 1 (6) : 092-099,

Peixoto, J.R., Silva, G.C., Costa, R.A., de Sousa Fontenelle, J.R., Vieira, G.H., Filho, A.A. and dos Fernandes Vieira, R.H. (2011). In vitro antibacterial effect of aqueous and ethanolic moringa leaf extracts, Asian Pac. J. Trop. Med., 4(3): 201-204.

Pretorious, J.C. (2003). Antiinfective Agents, Current Medicinal Chemistry, 2 : 335-353.

Price, M.L. (2007). The moringa Tree. ECHO technical l note. Revised edition, 11-12.

Rahman, M.M., Islam, M.R.,Uddin, M.B. and Aktaruzzaman, M. (2010). Prevalence of subclinical mastitis in dairy cows reared in Sylhet district of Bangladesh. Int. J. BioRes., 103 : 
23-28.

Rahman, M.M., Rahman, M.M., Akhter, S., Jamal, M.A., Pandeya, D.R., Haque, M.A., Alam, M.F. and Rahman, A. (2010). Control of coliform bacteria detected from diarrhea associated patients by extracts of Moringa oleifera. Nepal Med. Coll. J., 12 (1): 12-19.

Rajnarayana, K., Reddy, M.S., Chaluvadi, M.R. and Krishna, D.R. (2001). Biflavonoids classification, pharmacological, biochemical effects and therapeutic potential, Indian $J$ Pharmacol., 33 : 2-16.

Ramachandran, C., Peter, K.V. and Gopalakrishnan, P. K. (1980). Drumstick (Moringa oleifera): a multipurpose Indian vegetable.Econ Bot., 34 : 276-283.

Raza,A., Muhammad, G., Sharif, S. and Atta,A. (2013). Biofilm producing staphylococcus aureus and bovine mastitis: A review. Molecular Microbiology Research, 3(1) : 1-8.

Renitta, R. E., Nepolean, P. and Anitha, J. (2009). Isolation, analysis and identification of phytochemicals of antimicrobial activity of Moringa oleifera Lam. Current Biotica., 3(1): 3339.

Samy, R. P. and Gopalakrishnakone, P. (2008). Therapeutic potential of plants as antimicrobials for drug discovery. $e C A M$., $1-12$.

Schalm, O.W., E.J. Caroll and N.C. Jain (1971). Bovine Mastitis. Lea and Febiger, Philadelphia, pp. 360.

Schalm,W.O and Noorlander,D.O. (1957). Experiments and observations leading to development of the California mastitis test, J. Am. Vet. Med. Assoc., 130 (5) : 199-204.

Schmidt, T. Koch, M. M. and Ehlers, M.M. (2017). Molecular Characterization of Staphylococcus aureus Isolated from Bovine Mastitis and Close Human Contacts in South African Dairy Herds: Genetic Diversity and Inter-Species Host Transmission. Front. Microbiol., 8 : 511.

Sharma, H., Maiti, S.K. and Sharma, K.K. (2007). Prevalence, etiology and antibiogram of microorganisms associated with subclinical mastitis in buffaloes in Durg, C.G. state. Int. J. Dairy Sci., 2 : 145-151.
Sharma, N., Maiti, S.K. and Sharma, K. K. (2007). Prevalence, etiology and antibiogram of microorganisms associated with Sub-clinical mastitis in buffaloes in Durg, Chhattisgarh State (India). International Journal of Dairy Science, 2: 145-151.

Sharma, N. and Maiti, S. K. (2010). Incidence, etiology and antibiogram of sub clinical mastitis in cows in durg, Chhattisgarh. Indian J. Vet. Res., 19 : 45-54.

Siddiq, A., Anwar, F., Manzoor, M. and Fatima, A. (2005). Antioxidant activity of different solvent extracts of Moringa oleifera leaves under accelerated storage of sunflower oil. Asian Journal of Plant Sciences. 4 : 630-635.

Sato, T., Usui, M., Konishi, N., Kai, A., Matsui, H. and Hanaki, H. (2017). Closely related methicillin-resistant Staphylococcus aureus isolates from retail meat, cows with mastitis, and humans in Japan. PLoS ONE, 12 (10): e0187319.

Singh, B. N., Singh, B. R., Singh, R. L., Prakash, D., Dhakarey, R., Upadhyay, G. and Singh, H.B.(2009). Oxidative DNA damage protective activity, antioxidant and antiquorum sensing Potentials of Moringa oleifera. Food Chemistry and Toxicology., 47: 1109-1116.

Snedecor, G.W. and Cochran, W.G. (2004). Statistical methods. 8th Edn. Oxford and IBH Publishing Co. Pvt. Ltd., Kolkata.

Sreelatha, S., Jeyachitra, A. and Padma, P.R. (2011). Antiproliferation and induction of apoptosis by Moringa oleifera leaf extract on human cancer cells. Food Chem. Toxicol., 49 (6) : 1270-1275.

Sreelatha, S. and Padma, P.R. (2009). Antioxidant activity and total phenolic content of Moringa oleifera leaves in two stages of maturity. Plant Foods Hum Nutr.,64 (4): 303-311.

Sumathi, B.R., Veeregowda, B.M. and Amitha, R. G. (2007). Prevalence and antibiogram profile of bacterial isolates from clinical bovine mastitis. Veterinary World., 1(8): 237- 238.

Tung, C.C. (2004). Application of PCR-RFLP on molecular epidemiological study of Staphylococcusaureus isolated from milk of dairy cows and goats. Master Thesis. Department of Veterinary Medicine.National Chung Hsing University).

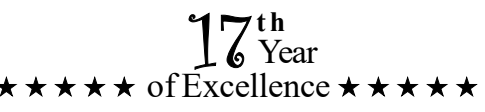

